\title{
POLYPHOSPHATE IN ZYGOMYCETES: A CYTOCHEMICAL STUDY
}

\author{
Allana Elesbão do Nascimento Shari'a ${ }^{1,2}$; Aline Elesbão do Nascimento ${ }^{1,2}$; Marcos Antonio Barbosa de Lima ${ }^{2}$; \\ Galba Maria de Campos-Takaki ${ }^{1,2 *}$; Wanderley de Souza ${ }^{3}$
}

${ }^{1}$ Núcleo de Pesquisas em Ciências Ambientais, Departamentos de Biologia e Química, Universidade Católica de Pernambuco, Boa Vista, PE, Brasil. ${ }^{2}$ Laboratório de Imunopatologia Keizo Asami (LIKA), Microscopia Eletrônica, Universidade Federal de Pernambuco (UFPE), Boa Vista, PE, Brasil. ${ }^{3}$ Laboratório de Ultraestrutura Celular, Instituto de Biofísica Carlos Chagas Filho, Universidade Federal do Rio de Janeiro, Rio de Janeiro, RJ, Brasil

Submitted: August 08, 2001; Retusrned to authors for corrections: November 22, 2001; Approved: May 13, 2002

\begin{abstract}
The inorganic phosphorus content, and distribution, structure and localization of polyphosphate in mycelia of zygomycetous fungi was evaluated. Ultrastructural cytochemistry was successfully used to identifying the localization and distribution of polyphosphate in Absidia cylindrospora, Gongronella butleri and Mucor javanicus. The results revealed differences in the cytochemical staining pattern in all species studied and a uniform labeling on the cellular surface (cell wall and citoplasmic membrane). Reaction products were observed in intracellular structures and cellular membrane. Intracellular staining was observed in trabecullar, vacuolar and vesicular structures, in dense bodies and in the cytoplasm. However, the cytochemical staining intensity varied during the cellular growth. Analytical procedure revealed the phosphorus content during cell growth. The results demonstrated that phosphorus content varied during cultivation time and could be related to the polyphosphate cytochemical staining. Polyhosphate functions such as storage and utilization are discussed.
\end{abstract}

Key words: Ultrastructural cytochemistry, polyphosphate, Zygomycetes.

\section{INTRODUCTION}

Members of Zygomycetes occur on or within a variety of substrata. Some species cause plant or animal diseases. They are often notable in culture because of their extremely fast growth rate, a characteristic important in their ability to compete in the soil. Some members not only are common soil saprophytes but also are important or are involved in technical aspects of industrial procedures causing spoilage of stored grains and diseases in humans, animals and plants. Some are used to produce commercially important products, such as organic acids, pigments, fermented oriental foods, alcohols and modified steroids $(3,5,9,25,31,32)$. Some members have been called "oportunistic fungi" to emphasize the aspect of a normally saprophitic fungus which can suddenly become parasitic and pathogenic when introduced in animal body, particularly in humans $(1,14,20,21,23,24,26,34,35)$.
In microbial cells, inorganic polyphosphate (polyP) plays a significant role in increasing cell resistance to unfavorable environmental conditions and in regulating different biochemical processes. PolyP is a chain of tens or many hundreds of phosphate (Pi) residues linked by high-energy phosphoanhydride bonds. It has long been hypothesized that polyphosphate performed numerous and varied biological functions depending on the need and its location in a specie, cell or subcellular compartment. Among these are phosphate and energy reserve, chelator of metals, buffer against alkali, involvement in cell envelope formation and function, gene activity control, bacterial transformation, disposal of pollulant phosphate, substrate for glucose phosphorylation, minimization of toxic effects of heavy metals, nucleic acid and phospholipid metabolism. The most valuable biological effect of polyphosphate is in physiological adjustment to growth, development, stress response and nutrient deprivation $(10,11,16,17,19,27,36)$.

\footnotetext{
* Corresponding Author. Mailing Address: Rua Nunes Machado, 42, Bloco J. UNICAP. 50050-900 - Boa Vista, PE. Brasil. Fax: (+5581) 3216-4043.
} 
The subcellular localization of the polyphosphate in different organisms is still controversial. Microscopists are familiar with the conspicous so-called volutin or metachromatic granules occurring in many microorganisms and it is generally agreed that these granules contain polyphosphates. A great difference is observed between prokaryotes and eukaryotes in their polyPmetabolizing enzymes. The synthesis and degradation of polyP in each specialized organelle or compartment are mediated by different sets of enzymes $(2,6,11,12,16,17,18,19,36)$.

Polyphosphates have been known to occur in numerous filamentous fungi and in the yeasts. The ability to acumulate polyP as a response of physiological adaptation during growth and development has been observed in some fungi. In these organisms polyphosphate cover a wide range of molecular sizes, particularly those with low molecular weight and are found in the form of dense metachromatic granules $(7,22,29,30,33)$.

The present paper reports the quantification of inorganic phosphorus, localization, structure and distribution of polyphosphate in the mycelium of Absidia cylindrospora, Gongronella butleri and Mucor javanicus.

\section{MATERIALS AND METHODS}

Microorganisms and culture conditions - Absidia cylindrospora (URM 3351) HAGEN, Gongronella butleri (URM 2151) (LENDNER) PEYRONEL and DAL VASCO, and Mucor javanicus (URM 1989) WHEMER (Mucorales - Zygomycetes) were kindly supplied by the Culture Collection of the Universidade Federal de Pernambuco. The cultures of Zygomycetes were mantained on Difco PDA (Potato Dextrose Agar) slants, incubated at $26^{\circ} \mathrm{C}$. The liquid medium used for large scale cultures was SMM (Synthetic Medium for Mucoralean) modified (4) without agar. Actively growing mycelia, grown on PDA, was transferred to Erlenmeyer flasks containing $40 \mathrm{ml}$ of SMM and incubated during 15 days, at $26^{\circ} \mathrm{C}$, at $250 \mathrm{hz}$. All samples were prepared in five replicas.

Growth curves - Samples collected at 3, 6, 9, 12 and 15 days of culture were submitted to liophylization and mantained in a vacuum dissecator until constant weight. The final value corresponded to arithmetic media of five replicas of each sample.

Analytical procedure - Liophylized samples (2mg) corresponding to $3,6,9,12$ and 15 days of culture were mixed in distilled water, and frozen during 24 hours. After this period, samples were thawed, and then disrupted with glass stick and centrifuged at $3000 \mathrm{rpm}$, during 15 minutes. The supernatant was used to determine polyphosphate content as inorganic phosphorus form. Total inorganic phosphorus content was determined by using the Sigma Kit - Fiske and Subbarow method. To each sample of $1 \mathrm{ml}$ of supernatant, $1 \mathrm{ml}$ of distilled water, ammonium molibdate $2.5 \%$ and ascorbic acid $5.0 \%$ were added, and the samples were boiled for 5 minutes. Samples were analysed through spectrophometry at $660 \mathrm{~nm}$.

\section{Electron microscopy}

Routine studies - Samples of Absidia cylindrospora, Gongronella butleri and Mucor javanicus, grown in liquid SMM, were collected after 3, 6, 9, 12 and 15 days of culture. Samples were washed twice in PBS (phosphate-buffered saline) pH 7.2 for 10 minutes and fixed in $2.5 \%$ glutaraldehyde, $0.1 \mathrm{M}$ cacodylate buffer $\mathrm{pH} 7.4$, during 2 hours, at room temperature, post-fixed in $1.0 \%$ osmium tetroxide for 1 hour at room temperature. Post-fixation was followed by washing in $0.1 \mathrm{M}$ cacodylate buffer, $\mathrm{pH}$ 7.4. Samples were dehydrated in acetone and embedded in Epon. Samples were cut in a REICHERT JUNG ultramicrotome, collected on copper grids and contrasted with uranyl acetate and lead citrate. Eletronmicrographs were obtained in a JEOL 100-CX (80 $\mathrm{Kv})$ transmission electron microscope.

Polyphosphate cytochemistry - The cytochemical detection of polyphosphates was performed according to Ebbel et al. 1958 (8). Absidia cylindrospora, Gongronella butleri and Mucor javanicus samples, grown in liquid SMM, were collected after 3, 6, 9, 12 and 15 days of culture. Samples were washed twice in PBS, pH 7.2 for 10 minutes, fixed in $2.5 \%$ glutaraldehyde, $0.1 \mathrm{M}$ cacodylate buffer $\mathrm{pH} 6.5$ during 1 hour at $4^{\circ} \mathrm{C}$ and washed in distilled water. Samples were incubated in $2 \%$ lead nitrate solution, pH 3.4 during 4 hours at $4^{\circ} \mathrm{C}$, and in $1 \%$ ammonium sulphite, during 30 minutes at $4^{\circ} \mathrm{C}$. After this period, samples were washed in distilled water, post-fixed in $1.0 \%$ osmium tetroxide for 1 hour at room temperature. Post-fixation was followed by washing in $0.1 \mathrm{M}$ cacodylate buffer, $\mathrm{pH}$ 7.4. Samples were dehydrated in acetone and embedded in Epon. Thin sections and photographs were obtained as described previously. Control samples were incubated in trichloroacetic acid after the fixation during 6 hours at $4^{\circ} \mathrm{C}$. After this period, samples were treated as cited before.

\section{RESULTS}

Figs. 1, 2 and 3 exhibit Absidia cylindrospora, Gongronella butleri and Mucor javanicus growth curves and the inorganic polyphosphate content, respectively. It was possible to observe an increase in dry weight in the first three days of culture. After this, a progressive decrease in the dry weight was observed. A similar pattern of cell growth was observed among the species studied.

Absidia cylindrospora exhibited the lowest phosphorus content on the third day of growth compared to other species. A visible phosphorus content decrease was observed on the sixth day of growth. In the ninth day the phosphorus content increased and reached the maximum value on the twelfth day of 


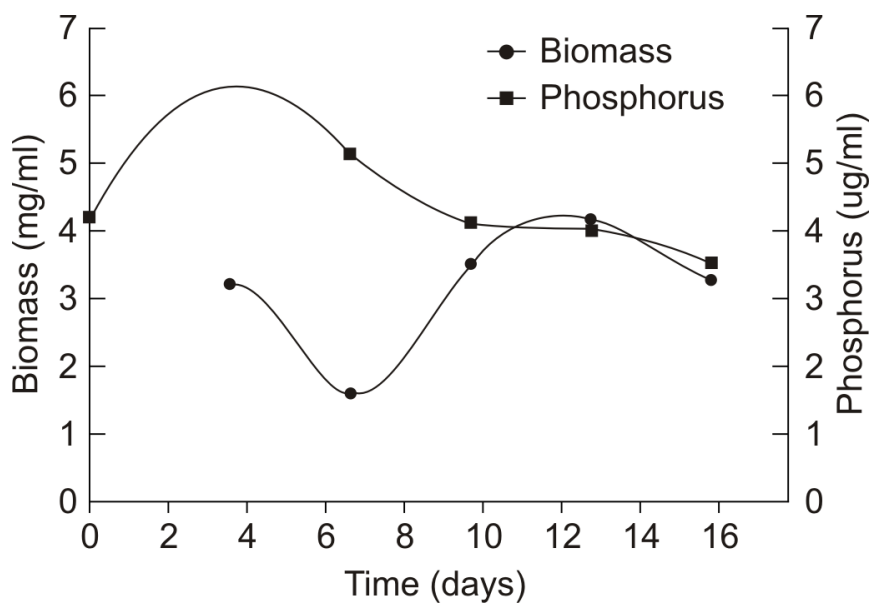

Figure 1. Absidia cylindrospora growth curve and inorganic phosphorus content.

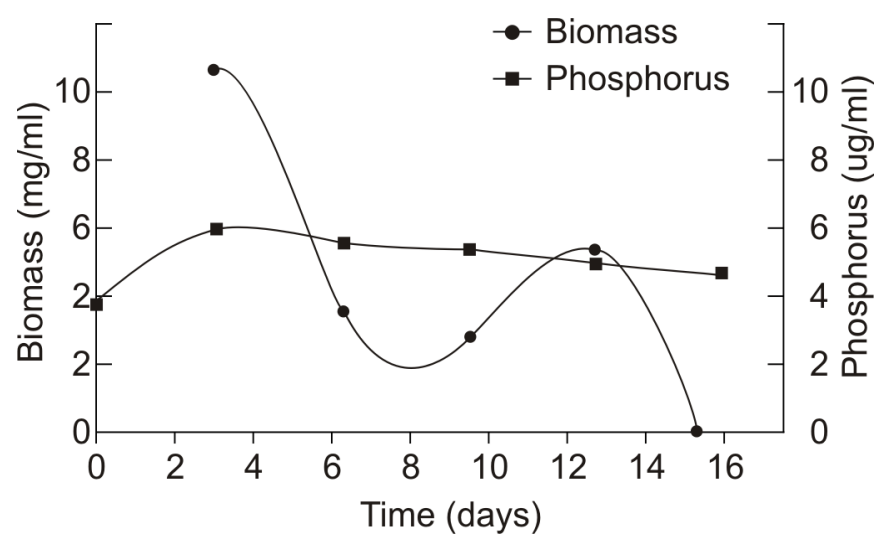

Figure 2. Gongronela butleri growth curve and inorganic phosphorus content.

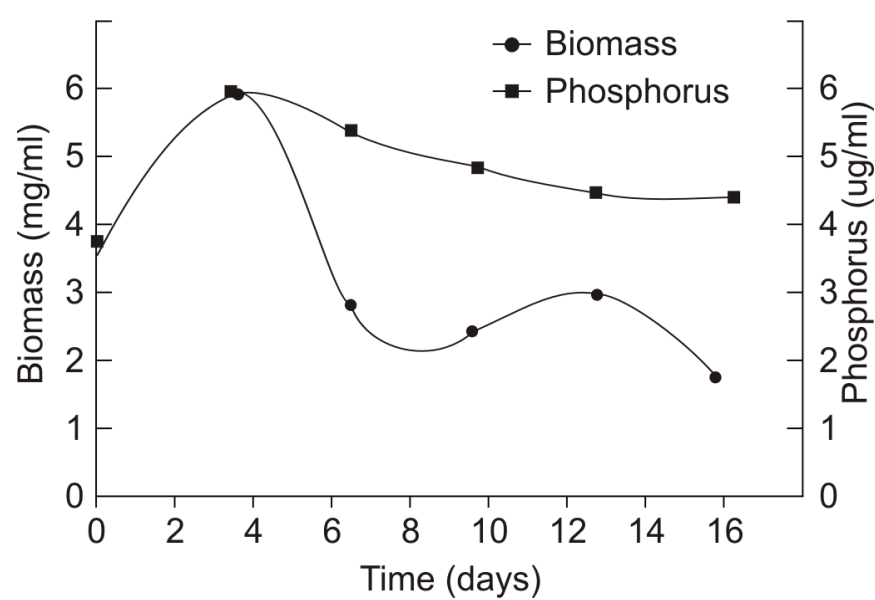

Figure 3. Mucor javanicus growth curve and inorganic phosphorus content culture. After this period, there was a new decrease which was accentuated after fifteen days of growth. During the initial period of growth, cells of Gongronella butleri and Mucor javanicus had substantially higher inorganic phosphorus levels than cells on the final period of cultivation. A pattern similar to that exhibited by Absidia cylindrospora was observed for Gongronella butleri and Mucor javanicus.

Figs. 4, 5 and 6 show the ultrastructure of Absidia cylindrospora, Gongronella butleri and Mucor javanicus cells, respectively. Cells presented homogeneous cytoplasm, thin cell wall and well defined organelles, such as mitochondria, lomassomes, endoplasmic reticulum, electron-dense bodies and

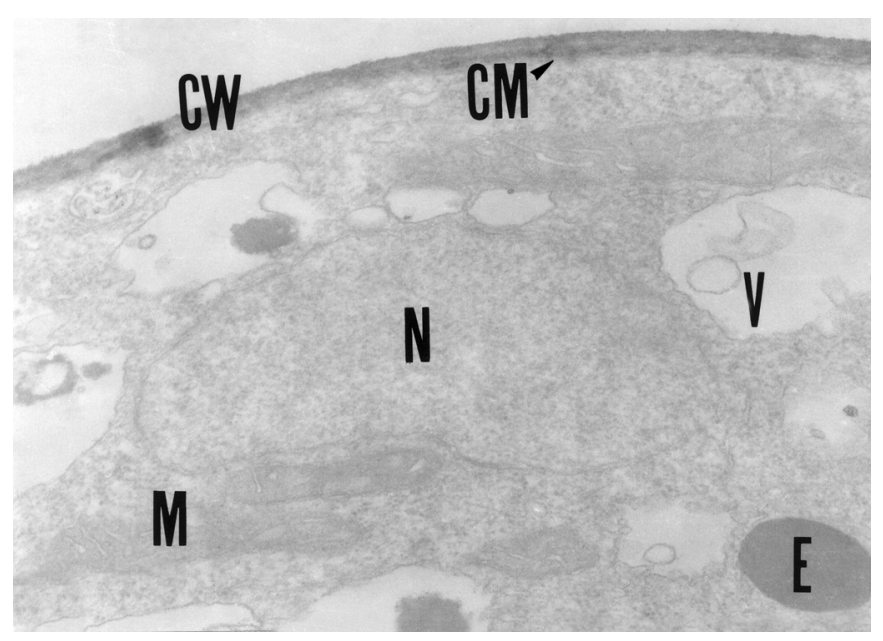

Figure 4. Absidia cylindrospora - Cell wall (CW), Cytoplasmic membrane (CM), Vacuoles (V), Nucleus (N), Electron dense bodie (E), Mitochondria (M) $34.000 \mathrm{X}$.

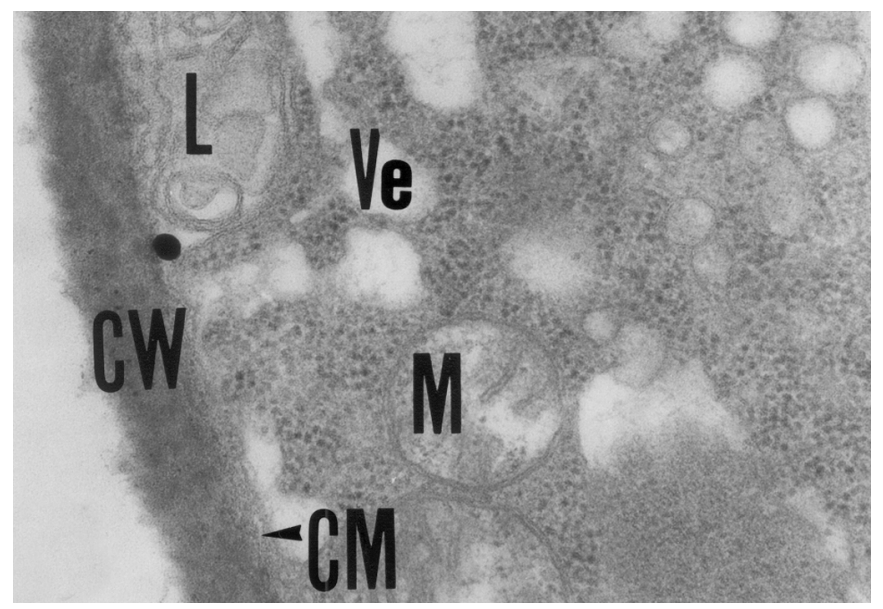

Figure 5. Gongronela butleri. Cell wall (CW), Cytoplasmic membrane (CM), Mitochondria (M) and Lomassome (L), Vesicules (Ve). 40.000 X. 
vesicles at the initial period of growth. Some hyphae presented septa, inumerous vacuoles and multivesicular bodies (Fig. 7). The cellular wall became thicker after six and twelve days of cultivation (Fig. 8). The cytoplasm became heterogeneous after fifteen days. The cell wall presented different layers and became thicker compared to those observed in cells with twelve days. A intense process of vacuolization was observed through the cell growth (Figs. 9 and 10).

Gongronella butleri presented the highest surface polyphosphate labeling and the presence of electron-dense bodies in the cytoplasm (Fig. 11). Mucor javanicus exhibited the highest polyphosphate labeling in the area correspondent to the contact between cell wall and cytoplasmatic membrane (Fig. 12). Reaction products were observed in different

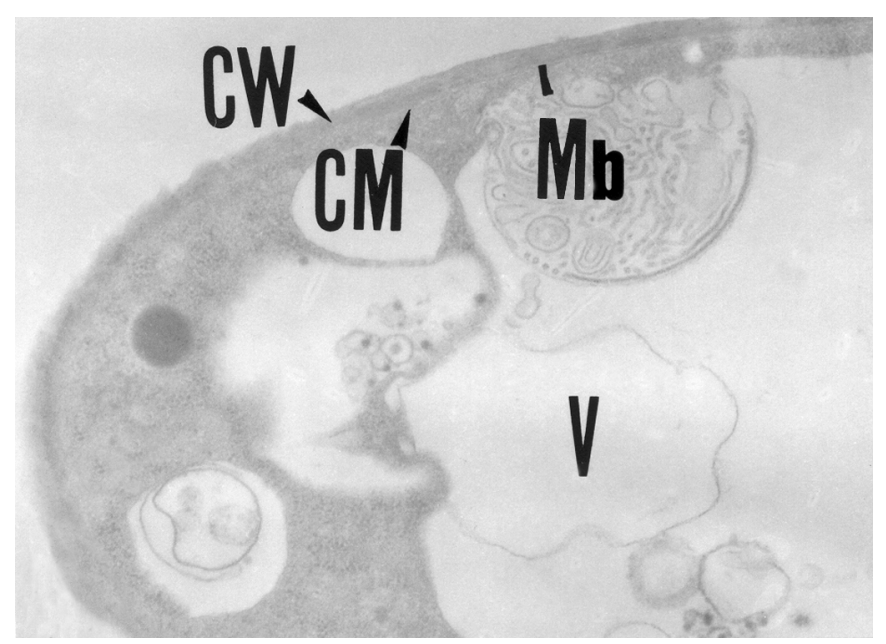

Figure 6. Mucor javanicus. Cell wall (CW), Cytoplasmic membrane (CM), Vacuoles (V), Multivesicular body (Mb). 20.000 X.

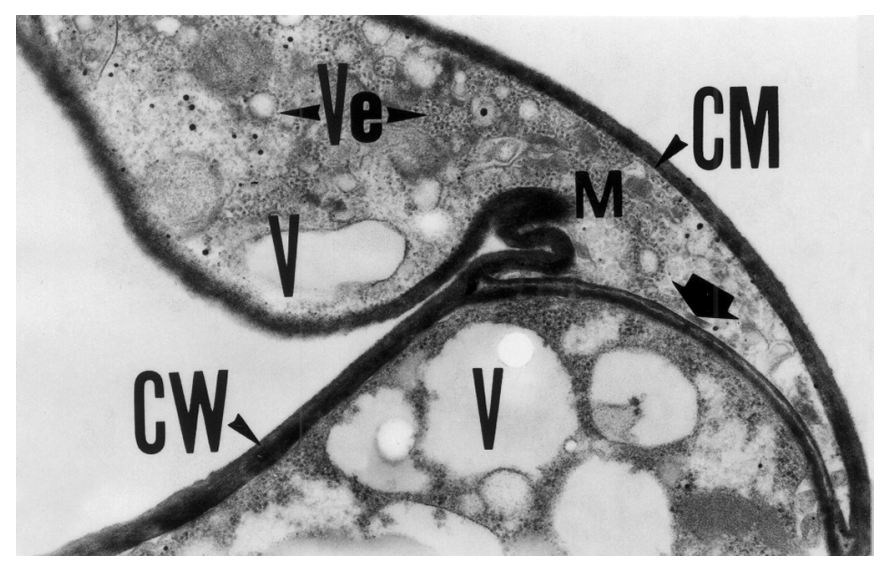

Figure 7. Absidia cylindrospora Cell wall (CW), Cytoplasmic membrane (CM), Mitochondria (M), Vesicules (Ve), Vacuoles (V), Mycelia differentiation septum area (arrow). 20.000 X.

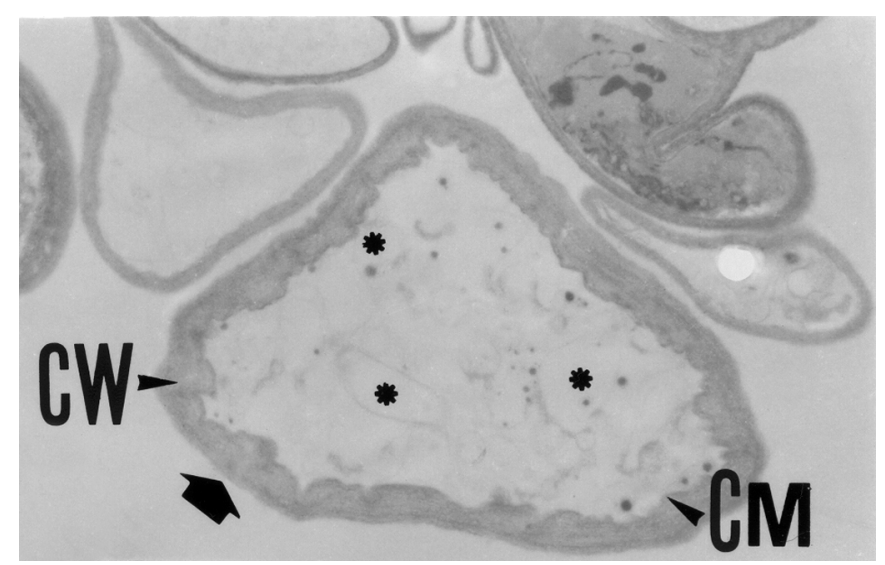

Figure 8. Absidia cylindrospora. Cell wall (CW), Cytoplasmic membrane (CM). Note the thickeness of cell wall (arrow), and an intense vacuolization process $(*) 9.000 \mathrm{X}$

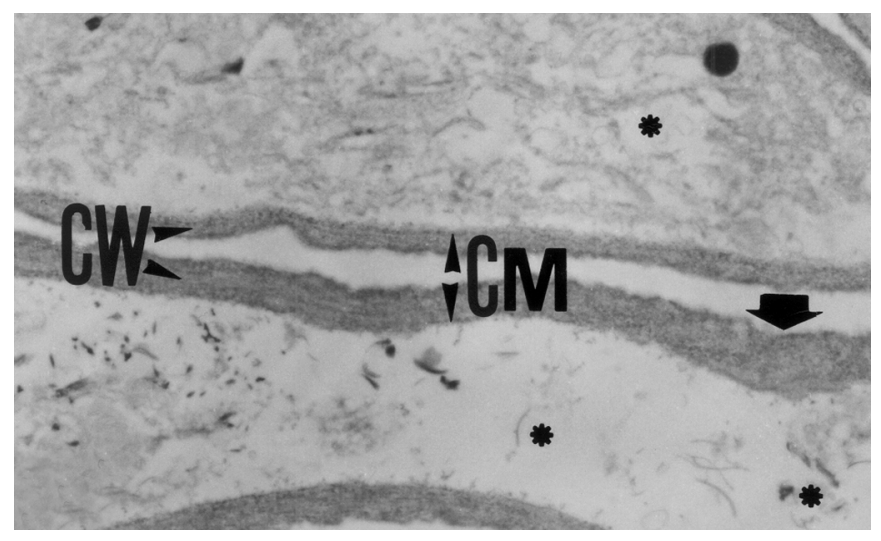

Figure 9. Gongronella butleri. Cell wall (CW), Cytoplasmic membrane (CM), Note the thickeness of cell wall (arrow), intense vacuolization process $(*) 9.000 \mathrm{X}$

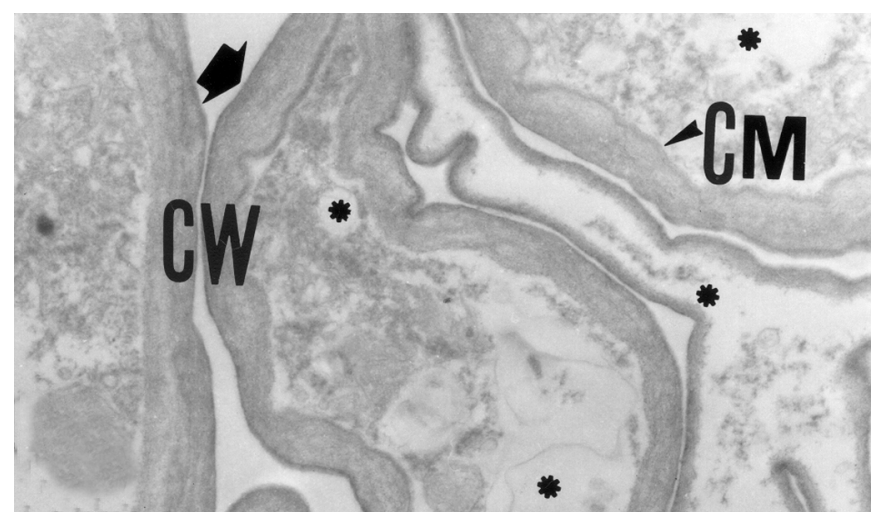

Figure 10. Mucor javanicus Cell wall (CW), Cytoplasmic membrane (CM), Note the thickeness of cell wall (arrow), intense vacuolization process $(*) 9.000 \mathrm{X}$ 
intracellular structures. All species presented polyphosphate labeling in vacuoles in the form of internal granular precipitates, reaction products in their membranes or in the form of electrondense bodies or deposits associated to membranes (Figs. 13 and 14). The highest content of polyphosphate deposits were observed in Gongronella butleri and Absidia cylindrospora compared to Mucor javanicus (Figs. 11, 13 and 14). An intense polyphosphate labeling was higher in cells with three days of cultivation. Indeed, Absidia cylindrospora cells with nine days of cultivation presented the highest intense labeling in the cell surface (Fig. 15).

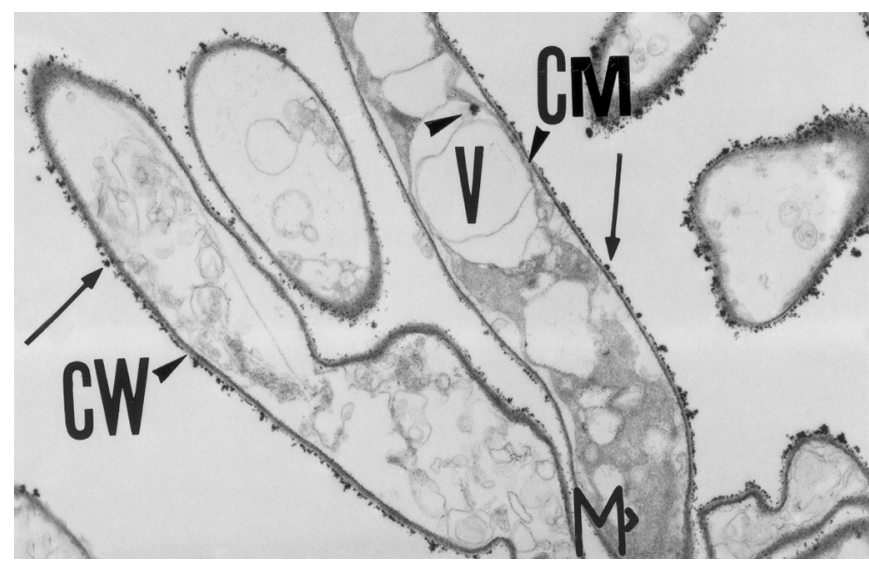

Figure 11. Gongronella butleri. Cell wall (CW), Cytoplasmic membrane (CM), Mitochondria (M), Vacuoles (V). Intense cell surface polyphosphate labeling (arrows). Electron dense bodies (arrowhead). 12.730X.

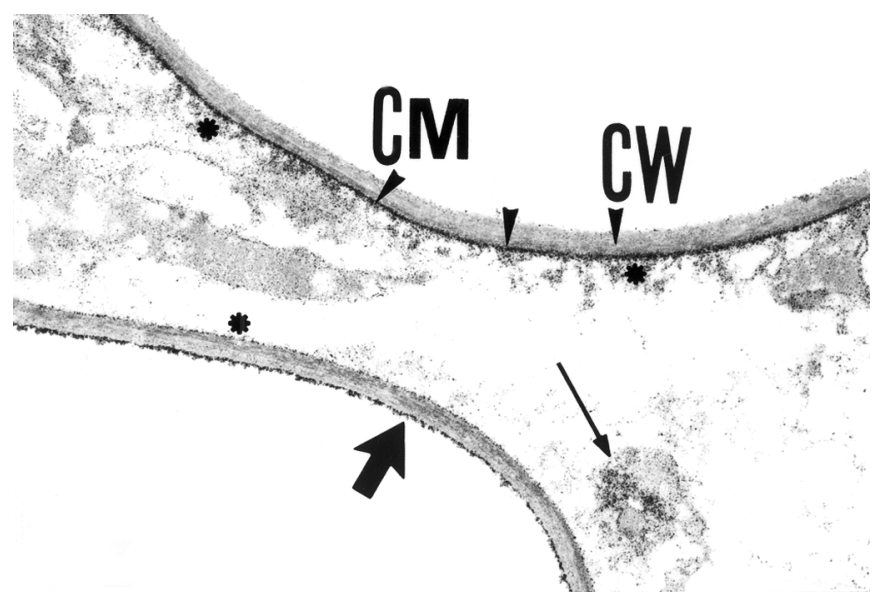

Figure 12. Mucor javanicus. Cell wall (CW), Cytoplasmic membrane (CM). Reaction products in cell surface (arrows), and outside of plasmatic membrane (arrowhead), cytoplasmic face of cell membrane $\left(^{*}\right)$ and disperse in cytoplasm (thin arrow), $20.000 X$.

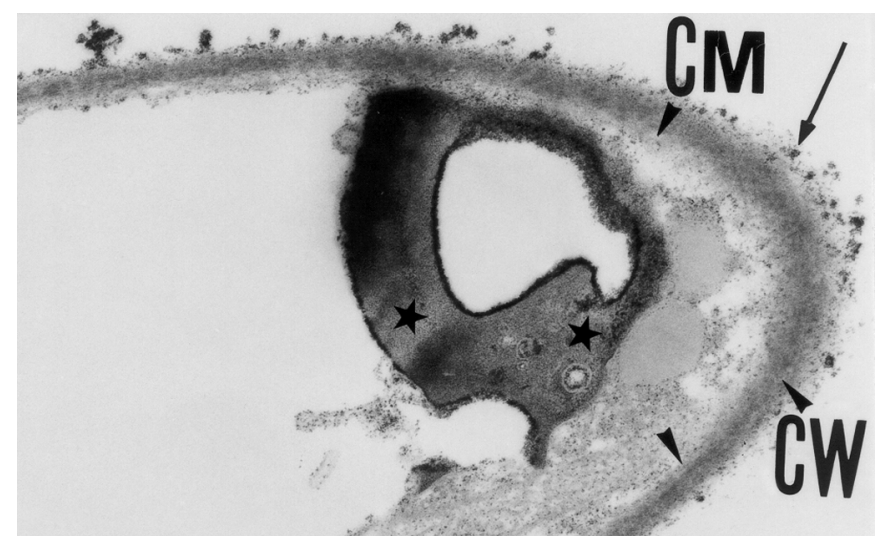

Figure 13. Absidia cylindrospora. Cell wall (CW), Cytoplasmic membrane (CM). Reaction products in cell surface (arrows), and in cytoplasmic face of the plasma membrane (arrowhead) and electron dense deposits within vacuoles ( ). 36.000 X.

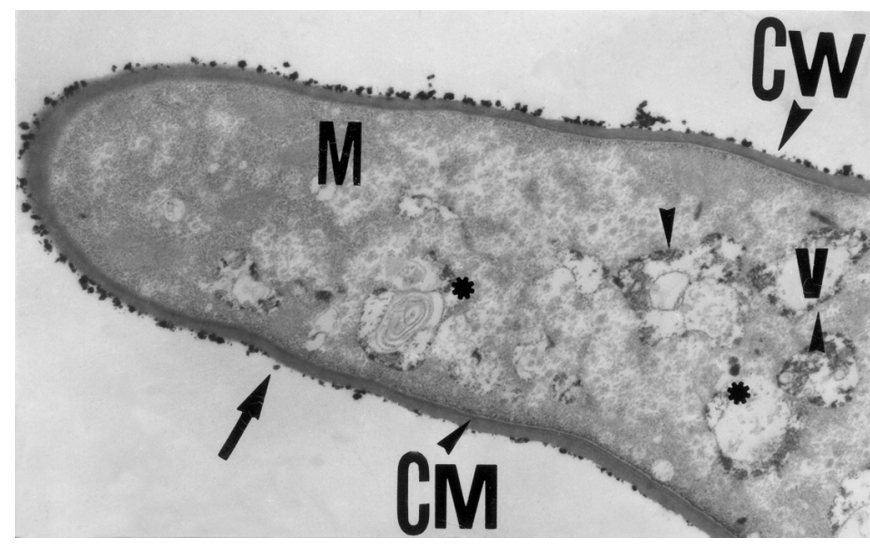

Figure 14. Mucorjavanicus. Cell wall (CW), Cytoplasmic membrane (CM), Mitochondria (M), Vacuole (V). Reaction products in cell surface (arrows), and in the plasma membrane of vacuoles (arrowhead) and electron dense deposits within vacuoles (*). 10.000 X.

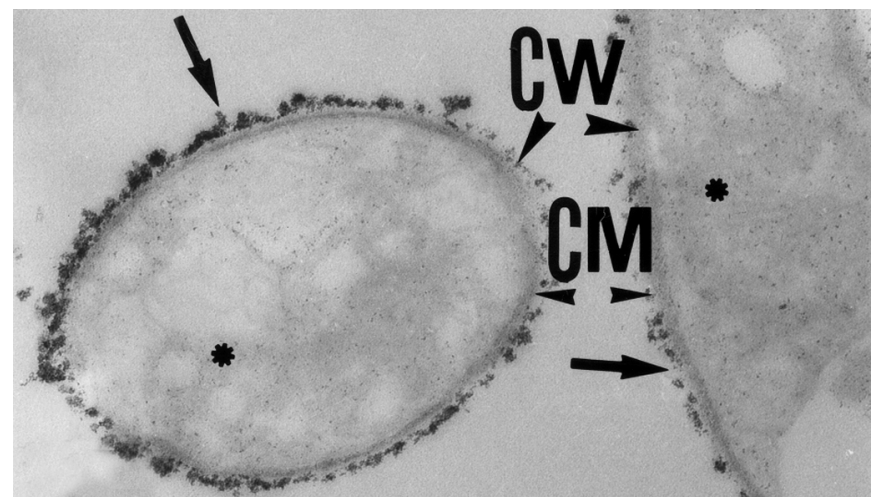

Figure 15. Absidia cylindrospora. Cell wall (CW), Cytoplasmic membrane (CM). Reaction products in cell surface (arrows), and cytoplasmic labeling $(*) .20 .000 \mathrm{X}$. 


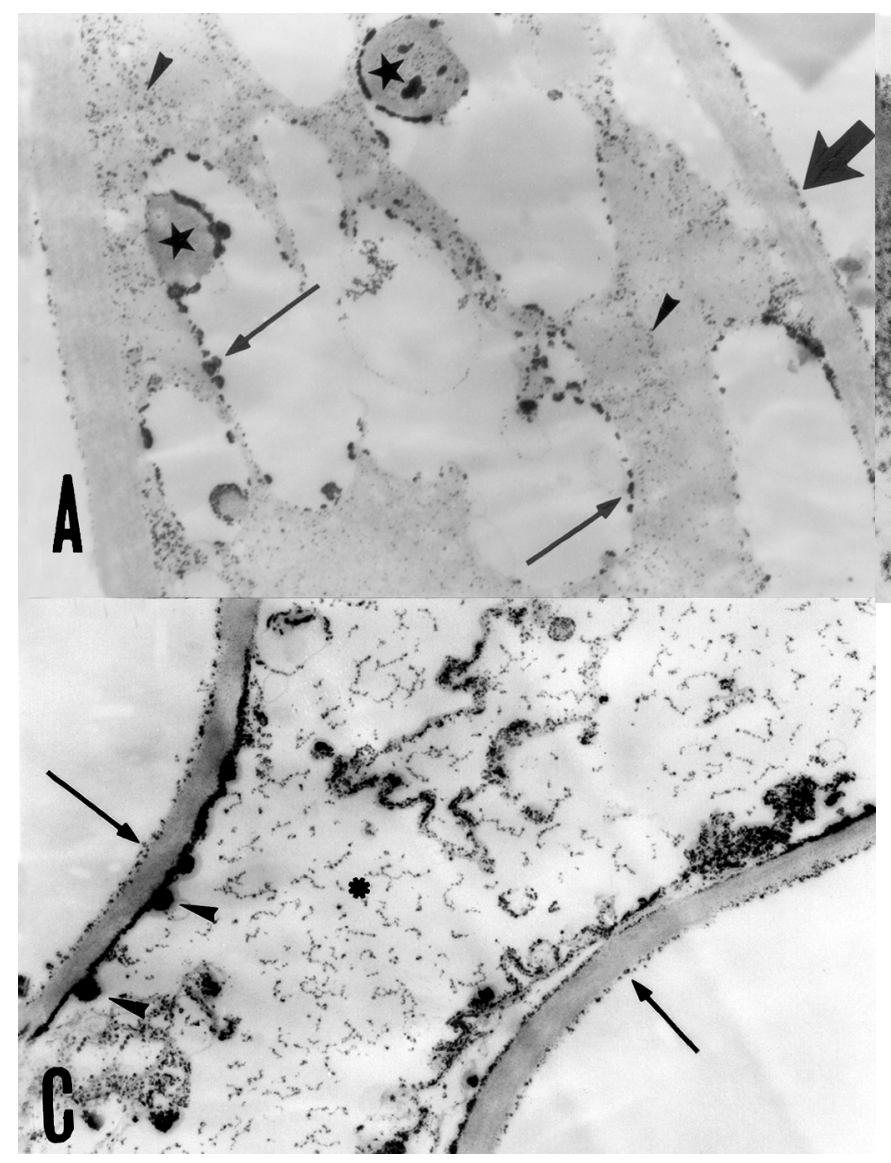

Figure 16. Mucor javanicus. A - Reaction products in cell surface (arrows), cytoplasm labeling (arrowhead) and electron dense deposits within vacuoles (thin arrow). Electron dense inclusions containing reaction products $\left(^{*}\right) .20 .000 \mathrm{X}$. B - Thick cell wall with a decrease in polyphosphate labeling (arrow); cytochemical labeling in vacuole membrane (arrowhead); electron dense inclusions associated to cytoplasmic face of cell membrane ( ). $40.000 \mathrm{X}$. C-surface labeling (arrow), electron dense bodies (arrowhead), cytoplasmic labeling (*). 20.000 X.

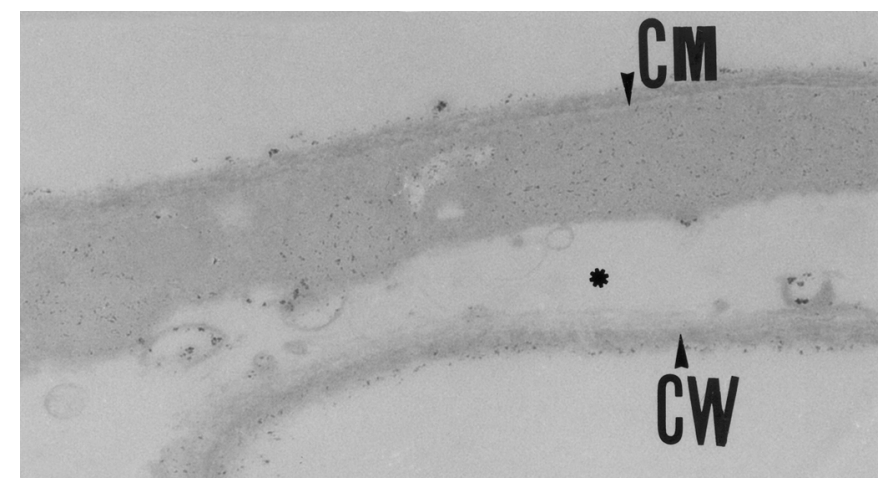

Figure 17. Absidia cylindrospora. Cell wall (CW), Cytoplasmic membrane $(\mathrm{CM})$, intense vacuolization $\left(^{*}\right) .30 .000 \mathrm{X}$.
After nine days of cultivation Mucor javanicus cells, exhibited a low intensity of polyphosphate labeling in cell surface. However, reaction products were observed in cell membrane, cytoplasm and electron dense precipitates. Cells with twelve days exhibited an intense labeling in the cell membrane, vacuoles and inclusions. On the fifteenth day of cultivation cells exhibited the highest labeling intensity in vacuoles, cytoplasm and cell surface compared to Absidia cylindrospora and Gongronella butleri (Figs. 16 A-C). Electron-dense bodies and inclusions were not observed in samples on the fifteenth day of cultivation.

Samples with twelve days of cultivation showed a decrease of the polyphosphate reaction products at the cell surface of all species studied and the lowest intensity labeling was observed in Absidia cylindrospora. The cells presented an intense vacuolization process and an increase of the cell wall thickness (Fig. 17).

\section{DISCUSSION}

The occurrence of polyphosphate has been reported for various organisms, both eukaryotes and prokaryotes. The cytochemical deteccion of polyphosphate shows very distinct features among these organisms. The cytochemical staining of cellular polyphosphate by lead salts permit the observation of polyphosphate precipitated in situ with lead as metachromatic granules after exposure to the electron beam $(8,11)$. However, the polyphosphate distribution in Zygomycetes has not previously been reported. Localization of polyphosphate within a cell also depends on the chain lenght. Low molecular weight polyphosphate are located in the cytoplasm, in granules, free in the cytosol or bound to cytoplasm compounds such as ribonucleic acids. More highly polymerized polyphosphates are found in the plasma membrane and in the cell wall (18).

Electron microscopic investigations published in recent years have shown that polyphosphate appears as electrondense granules in association with a number of subcellular entities. Associations among polyphosphate granules and cell wall, cell membrane, vacuoles and in cytoplasm were reported $(2,32,35)$.

The results presented in this work revealed the polyphosphate location, structure and distribution in Mucor javanicus, Gongronella butleri and Absidia cylindrospora. The present findings showed that the Zygomycetes studied exhibited a cytochemical polyphosphate labeling in different structures as 
well different amounts according to the specie. These results reflect the different ways in which the species store polyphosphate and may represent different functions related to its location. Also, a uniform polyphosphate labeling on the cellular surface, cell wall and cell membrane of all species studied was visualized. The presence of electron-dense bodies, trabecullar structures and vacuoles with reaction products was observed. In the cytoplasm the polyphosphate labeling was observed as dispersed patches or linear arrangements in the membrane of vacuoles. Electron-dense bodies presenting core with labeling intensity lower than the peripheric area were visualized. These results suggest that the Zygomycetes studied present polyphosphate molecules with different chain lenghts.

The cellular location, structure and distribution of polyphosphate are related to the cell growth phase. This suggests that the polyphosphate is developped in distinct phases of the growth cycle and is accumulated under certain growth conditions. Bacteria accumulate polyphosphates only under adverse growth conditions, others appear to accumulate during exponential growth phase in spite of the synthesis of nucleic acids, which depends of polyphosphate degradation $(2,19,21)$.

In fungi, metabolic changes associated to $\mathrm{pH}$ of the culture medium, vacuolar $\mathrm{pH}$, phosphorus content and polyphosphate chain size in cells on stationary and logarithmic growth phases were demonstrated in Saccharomyces cerevisiae, Gigaspora margarita and Candida humicola $(12,24,31)$.

Polyphosphates have been implicated in energy storage due to the energy liberated in hydrolysis of their phosphoanhydride bonds, their associations with energy producing cellular structures and their enzymatic synthesis from cellular energy carriers $(12,18,19,21)$.

It is very apparent that there were changes in the phosphorus content that take place during the growth cycle. The analytical study performed in this work revealed that the cells in exponential growth phase exhibited the highest inorganic phosphorus content compared to cells in other growth phases, indicating the necessity to evolve metabolic activities in this period of cellular growth. The inorganic phosphorus content decrease during the cellular growth cycle suggesting its utilization for molecular synthesis of cellular compounds.

The increase in the phosphorus content on the twelfth day of growth observed in this work presumably resulted from the transport of newly formed inorganic phosphorus out of intracellular structures from polyphosphate degradation, since newly phosphorus content was not added in the medium.

Some authors have suggested a mural localization of polyphosphate. The presence of polyphosphate on cellular surface of whole cells was observed in Neisseria gonorrheae, Propionibacterium acnes and Helicobacter pilori $(2,17)$.

In fungi, the presence of polyphosphate was detected in isolated cell walls and mycelia of Zygomycetes and in Neurospora crassa and Kluyveromyces marxianus by analytical methods $(4,7,35)$. The cytochemical localization of polyphosphate in the yeast Saccharomyces cereviseae was observed outside of plasma membrane (32).

The results obtained in this work revealed an intense polyphosphate labeling in cell wall and cell membrane of all species studied, similar to what have been described in bacteria.

The polyphosphate aggregation with the cell surface is involved in the maintenance of cytoplasmic membrane integrity and in the transport-associated phosphorylation of glucose and glucose derivatives (30). The occurrence of amorphous polyphosphate cytoplasmic precipitates was detected in Helicobacter pilori (2).

Mucor javanicus was the only Zygomycetes to present amorphous polyphosphate precipitated in cytoplasm.

The existence of vacuolar polyphosphate is a well known phenomenom in yeasts and bacteria. In these organisms the vacuolar polyphosphate is associated to storage material and functions as biological cation exchanger. Electron dense bodies containing polyphosphate were observed in Nostoc punctiforme, Helicobacter pilori and Propionibacterium acnes. These results were confirmed by rays X-microanalysis $(2,15,17,18,32,35)$.

Despite of central roles of phosphate and ATP in metabolism and regulation, scant attention has been given to ubiquitous, abundant and conserved polyphosphate in fungi. The physiological roles of polyphosphate could be determined through studies on its distribution and structure at cellular level in order to identify and characterize the enzymes involves in polyP metabolism.

\section{ACKNOWLEDGEMENTS}

The authors are greateful to PRONEX, PADCT and CNPq for the financial support.

\section{RESUMO}

\section{Polifosfato em Zygomycetes: um estudo citoquímico}

O conteúdo de fósforo e a distribuição, estrutura e localização de polifosfato em micélios de Zygomycetes foram avaliados. A citoquímica ultrastrutural foi utilizada com sucesso para identificar a localização e a distribuição de polifosfato em Absidia cylindrospora, Gongronella butleri e Mucor javanicus. Os resultados obtidos revelaram diferenças no padrão de marcação citoquímica em todas as espécies estudadas, bem como, uma marcação uniforme sobre a superfície celular, correspondendo à parede celular e à membrana citoplasmática. Produtos de reação, resultantes da marcação citoquímica, foram também visualizados em estruturas intracelulares e na membrana celular. Estruturas trabeculares, vacuolares, vesiculares, sob a forma de corpos eletron densos e grânulos dispersos no citoplasma foram visualizadas. Adicionalmente, a marcação 
citoquímica variou durante as diferentes fases do crescimento celular. O conteúdo de fósforo variou ao longo do crescimento celular e do tempo de cultivo, possivelmente devido aos padrões da marcação citoquímica observados por meio da microscopia eletrônica de transmissão. São discutidas as funções do polifosfato como material de reserva e sua utilização.

Palavras-chave: citoquímica ultraestrutural, polifosfato, Zygomycetes.

\section{REFERENCES}

1. Attapattu, M.C. Acute rhinocerebral mucomycosis is caused by Rhizopus arrhizus from Sri Lanka. J. Trop. Med. Hyg., 98: 355-358, 1995.

2. Bode, G.; Mauch, F.; Ditschuneit, H.; Malfeertheiner, P. Identification of structures containing polyphosphate in Helicobacter pilori. J. Gen. Microbiol., 139: 3029-3033, 1993.

3. Brown, E.D.; Yada, R.Y.; Maragon, A.G. The dependence of the lipolytic activity of Rhizopus arrhizus lipase on surfactant concentration in aerosol-OT/isooctane reverse micelles and its relationship to enzyme strcuture. Biochim. Biophys. Acta., 1161, 66-72, 1993.

4. Campos Takaki, G.M.; Beakes, G.W.; Dietrich, S.M. Electron microscopic X-ray microprobe and cytochemical study of isolated cell walls of mucoralean fungi. Trans. Br. Mycol. Soc., 80: 536-541, 1983.

5. Certik, M.; Balteszova, L.; Sabjidor, J. Lipid formation and g-linolenic acid production by Mucorales fungi on sunflower oil. Lett. Appl. Microbiol., 25: 101-105, 1997.

6. Dawes, E.A.; Senior, P.J. The role and regulation of energy reserve polymers in microorganisms. Adv. Microbiol. Physiol., 10: 135166, 1973.

7. Dietrich, S.M. Presence of polyphosphate of low molecular weight in Zygomycetes. J. Bacteriol., 127: 1408-1413, 1976.

8. Ebbel, J.P.; Colas, J.; Muller, S. II. Mise au point de méthodes de détection cytochimiques spécifiques des polyphosphates. Exp. Cell Res., 15: 28-36, 1958.

9. Endo, A.; Takeshima, H.; Kuwabara, K. Acetil CoA-carboxilase inhibitors from the fungus Gongronella butleri. J. Antib., 38: 599604, 1985.

10. Greenfield, N.J.; Hussain, M.; Lenard, J. Effects of growth stage and amines on cytoplasmic and vacuolar $\mathrm{pH}$, phosphate levels in Saccharomyces cerevisiae: a P-nuclear magnetic resonance study. Biochim. Biophys. Acta, 926: 205-214, 1987.

11. Harold, F.M. Inorganic polyphosphate in biology: structure, metabolism and function. Bacteriol. Rev., 13: 772-794, 1966.

12. Ishige, K.; Noguchi, T. Inorganic polyphosphate kinase and adenylate kinase participate in the polyphosphate: AMP phosphotransferase activity os Escherichia coli. Proc. Natl. Acad. Sci. USA, 97: 1416814171, 2000.

13. Jensen, T.E. Electron microscopy of polyphosphate bodies in a bluegreen alga, Nostoc punctiforme. Arch. Microbiol., 62: 144-152, 1968.

14. Kimura, M.; Udagawa, S.; Toyazaki, N.; Iimori, M.; Hashimoto, S. Isolation of Rhizopus microsporus var. rhizopodiformis in the ulcer of human gastric carcinoma. J. Med. Vet. Mycol., 33: 137-139, 1995

15. Kjeldstad, B.; Nissen, M.H.; Bergan, A.S.; Evjen, K. Changes in polyphosphate composition and localization in Propionibacterium acnes after ultraviolet irradiation. Can. J. Microbiol., 37: 562-567, 1991.
16. Kornberg, A. Inorganic polyphosphate: toward making a forgotten polymer unforgettable. J. Bacteriol., 177: 491-496, 1995.

17. Kornberg, A.; Rao, N.N.; Ault-Riché, D. Inorganic polyphosphate: A molecule of many functions. Annu. Rev. Biochem., 68: 89-125, 1999.

18. Kulaev, I.S.; Vagabov, V.M. Polyphosphate metabolism in microorganisms. Adv. Microbiol. Physiol., 24: 83-169, 1983.

19. Kulaev, I.; Kulakovskaya, T. Polyphosphate and phosphate pump. Annu. Rev. Microbiol., 54: 709-734, 2000.

20. Lehrer, R.I.; Howard, D.H.; Sypher, P.S.; Edward, E.S.J.E.; Segal, G.P.; Winston, D.J. Mucormycosis. Ann. Int. Med., 93: 93-108, 1980.

21. Levy, S.A.; Schmiff, K.W.; Kaufman, L. Systemic zygomycosis diagnosed by fine needle aspiration and confirmed with enzyme immunoassay. Chest, 90: 146-148, 1986.

22. McGrath, J.W. \& Quinn, J.P. Intracellular accumulation of polyphosphate by the yeast Candida humicola G-1 in response to acid pH. Appl. Environm. Microbiol., 66: 4068-4073, 2000.

23. Mitchell, S.J.; Gray, J.; Morgan, M.E.; Hocking, M.D.; Durbin, G.M. Nosocomial infection with Rhizopus microsporus in preterm infants: association with wooden tongue depressors. Lancet., 17: 441-443, 1996.

24. Oliveri, S.; Cammarata, E.; Augello, G.; Mancuso, P.; Tropea, R.; Ajello, L.; Padhye, A.A. Rhizopus arrhizus in Italy as the causative agent of primary cerebral zygomycosis in a drug addict. Eur. J. Epidemiol., 4: 284-288, 1988.

25. Osmani, A.; Scrutton, M.C. The sub-cellular localization and regulatory properties of pyruvate carboxylase from Rhizopus arrhizus. Eur. J. Biochem., 147: 119-128, 1985.

26. Schipper, M.A.; Maslen, M.M.; Hogg, G.G.; Chow, C.W.; Samson, R.A. Human infection by Rhizopus azygosporus and the occurrence of azygospores in Zygomycetes. J. Med. Vet. Mycol., 34: 199-203, 1996.

27. Shirama, K.; Yazaki, Y.; Sakano, K.; Ohsumi, Y. Vacuolar function in the phosphate homeostasis of the yeast Saccharomyces cerevisiae. Plant. Cell Physiol., 37: 1090-1093, 1996.

28. Skorko, R. Polyphosphate as a source of phosphoryl group in protein modification in the archaebacterium Sulfolobus acidocaldarius. Biochemie, 71: 1089-1093, 1989.

29. Solaiman, M.Z.; Ezawa, T.; Kojima, T.; Saito, M. Polyphosphates in intraradical and extraradical hyphae of an arbuscular mycorrhizal fungus, Gigaspora margarita. Appl. Environm. Microbiol., 65: 56045606, 1999.

30. Tijssen, J.P.F.; Steveninck, J. van de; Bruijin, W.C. Cytochemical staining of a yeast polyphosphate fraction, localized outside the plasma membrane. Protoplasma, 125: 124-128, 1985.

31. Tombs, M.P.; Blake, G.G. Stability and inhibition of Aspergillus and Rhizopus lipases. Biochim. Biophys. Acta, 700: 81-89, 1982.

32. Trudel, J.; Asselin, A. Detection of chitin deacetylase activity after polyacrylamide gel electrophoresis. Anal. Biochem., 189: 249-253, 1990.

33. Urech, K.; Durr, M.; Boller, J.H.; Wieken, A.; Schwencke, J. Localization of polyphosphate in vacuoles of Saccharomyces cerevisiae. Arch. Microbiol., 116: 275-278, 1978.

34. Verweij, P.E.; Voss, A.; Donnelly, J.P.; de Pauw, B.E.; Meis, J.F. Wooden sticks as the source of a pseudoepidemic of infection with Rhizopus microsporus var. rhizopodiformis among immunocompromised patients. J. Clin. Microbiol., 35: 2422-2423, 1997.

35. West, B.C.; Oberle, A.D.; Kwong-Chung, K.J. Mucormycosis caused by Rhizopus microsporus var. microsporus: cellulitis in the leg of a diabetic patient cured by amputation. J. Clin. Microbiol., 33: 33413344, 1995.

36. Wood, H.G.; Clark, J.E. Biological Aspects of Inorganic Polyphosphate. Ann. Rev. Biochem, 57: 253-260, 1988. 